\title{
Determination of Natural Radioactivity in Aggregates from Western Mediterranean Region
}

\author{
F. PehlivanoĞLU ${ }^{a}$ AND Ş. KilinÇARSLAN ${ }^{b}$ \\ ${ }^{a}$ Suleyman Demirel Univ., Technical Education Fac., Construction Dept., Isparta, Turkey \\ ${ }^{b}$ Suleyman Demirel Univ., Engineering Fac., Civil Engineering Dept., Turkey
}

\begin{abstract}
Every material found in nature has a specific feature of the radioactivity. Depending on the degree of radioactivity, radioactivity effects are detrimental to human health. The use of these materials in the areas of human life can affect human health. Degree of radioactivity of these materials should be determined and usability of theirs should be controlled in buildings. In this study, determinations of natural radioactivity in aggregates used for construction were examined. As varieties of the aggregate of the region of Western Mediterranean: barite, olivine, tuff, aggregate, pumice, and andesite for the measurement of natural radioactivity was obtained. Materials were ground before they were used to determination of radioactivity and chemical analysis experiments. Of the powderized materials, by gamma-spectroscopic method there were carried out measurements of natural radioactivity in the Institute of Nuclear Sciences, Ege University. Degrees of natural radioactivity of materials that can be used as aggregate obtained from Western Mediterranean region were determined. The degree of radioactivity was compared with the values specified in the standards, the results were compared.
\end{abstract}

DOI: 10.12693 /APhysPolA.125.275

PACS: $93.85 . \mathrm{Np}$

\section{Introduction}

Construction aggregate is a broad category of coarse particulate material used in construction, including sand, gravel, crushed stone, slag, and recycled materials. Aggregates are a component of composite materials such as concrete and asphalt concrete. Production of aggregates for civil engineering and building construction is one of the world's major industries [1].

The building industry requires large quantities of low-cost materials and new products that may be substitutes for the widely used natural products as conventional building materials [2]. However, such new building materials may contain significant quantities of naturally or technologically enhanced levels of radioactivity [3]. Generally, the specific activities of ${ }^{238} \mathrm{U},{ }^{232} \mathrm{Th}$, and ${ }^{40} \mathrm{~K}$ in the building raw materials and their products mainly depend on geological and geographical conditions as well as geochemical characteristics of those materials [4].

Human populations have always been exposed to ionizing radiation from natural sources. Building materials is one of the sources which cause direct radiation exposure $[5,6]$. Knowledge of radioactivity present in building materials enables one to assess any possible radiological risks to human health [7-9].

\section{Materials and methods}

The study used six different building materials. Samples, commonly used as building materials in Isparta city, were randomly collected from local supplies. These are welded tuffs, pumice, andesite, aggregate, olivine, and barite.

The samples were crushed, sieved through meshes, homogenised and air-dried. The samples were cooled in moisture-free atmospheric medium. The samples were put into cylindrical plastic containers $(4 \mathrm{~cm}$ diameter,
$4 \mathrm{~cm}$ height), weighed and hermetically sealed. The sealed samples were then left for 4 weeks to allow for $\mathrm{Ra}$ and its short-lived progeny to reach radioactive equilibrium.

The concentration of the natural radioactivity $\left({ }^{226} \mathrm{Ra}\right.$, ${ }^{232} \mathrm{Th}$, and ${ }^{40} \mathrm{~K}$ ) in the material samples were determined using a $3 \times 3$ inch $^{2} \mathrm{NaI}(\mathrm{Tl}) \gamma$-ray spectrometric system. The detector is maintained in a vertical position in a lead cylindrical shield of $10 \mathrm{~cm}$ thickness and $60 \mathrm{~cm}$ height. The internal dimensions of the free surface within the shielding enclosure are $7.5 \mathrm{~cm}$ in diameter and $15 \mathrm{~cm}$ in depth. The power supply and the data acquisition of the energy spectra were achieved by using an integrated spectroscopy system from ORTEC. The system was calibrated for the $\gamma$-energy range $80 \mathrm{keV}$ to $1.76 \mathrm{MeV}$. The energy region for ${ }^{40} \mathrm{~K}, 1.46 \mathrm{MeV} \gamma$-rays, ${ }^{226} \mathrm{Ra}, 1.76 \mathrm{MeV}$ $\gamma$-rays and ${ }^{206} \mathrm{Th}, 2.61 \mathrm{MeV} \gamma$-rays were chosen as $1.38-$ $1.58,1.63-1.97$, and $2.41-2.67 \mathrm{MeV}$, respectively.

The standard sources for ${ }^{226} \mathrm{Ra}$ and ${ }^{232} \mathrm{Th}$ were prepared using known activity contents and mixing with the matrix material of phthalic acid powder. In order to avoid the loss of gaseous daughter products of ${ }^{226} \mathrm{Ra}$ and ${ }^{228} \mathrm{Th}$ which may lead to disturbance in radioactive equilibrium, the prepared standard sources were kept in sealed plastic container. Each sample was counted for a period of $10 \mathrm{~h}$.

\subsection{Radium equivalent activity $\left(R a_{\mathrm{eq}}\right)$}

The most widely used radiation hazard index $\mathrm{Ra}_{\mathrm{eq}}$ is called the radium equivalent activity. The radium equivalent activity is a weighted sum of activities of the ${ }^{226} \mathrm{Ra}$, ${ }^{232} \mathrm{Th}$, and ${ }^{40} \mathrm{~K}$ radio nuclides based on the assumption that $370 \mathrm{~Bq} \mathrm{~kg}^{-1}$ of ${ }^{226} \mathrm{Ra}, 259 \mathrm{~Bq} \mathrm{~kg}{ }^{-1}$ of ${ }^{232} \mathrm{Th}$ and $4810 \mathrm{~Bq} \mathrm{~kg}{ }^{-1}$ of ${ }^{40} \mathrm{~K}$ produce the same gamma ray dose rate. Radium equivalent activity can be calculated from the following relation [10]: 
$\mathrm{Ra}_{\mathrm{eq}}=\left(A_{\mathrm{Th}} \times 1.43\right)+A_{\mathrm{Ra}}+\left(A_{\mathrm{K}} \times 0.077\right)$,

where $A_{\mathrm{Th}}$ is the specific activity of ${ }^{232} \mathrm{Th}$ in $\mathrm{Bq} \mathrm{kg}^{-1}$, $A_{\mathrm{Ra}}$ is the specific activity of ${ }^{226} \mathrm{Ra}$ in $\mathrm{Bq} \mathrm{kg}{ }^{-1}, A_{\mathrm{K}}$ is the specific activity of ${ }^{40} \mathrm{~K}$ in $\mathrm{Bq} \mathrm{kg}^{-1}$.

\subsection{External radiation risk $\left(H_{\mathrm{ex}}\right)$}

Annual external (gamma) index $\left(H_{\text {ex }}\right)$ due to emitted gamma ray of each samples are calculated by the following equation [10]:

$$
H_{\mathrm{ex}}=\frac{C_{\mathrm{Ra}}}{370}+\frac{C_{\mathrm{Th}}}{259}+\frac{C_{\mathrm{K}}}{4810} \leq 1 .
$$

$H_{\text {ex }}$ value must be smaller than 1 in order to be negligible radiation damage.

\section{Results}

Materials ${ }^{238} \mathrm{U},{ }^{232} \mathrm{Th}$, and ${ }^{40} \mathrm{~K}$ activity was determined. The following table shows the average results of the samples. Mean values of the measured concentrations have been calculated for all the collected samples and are given in Table I.

TABLE I

Measured values of natural radio nuclides in samples.

\begin{tabular}{c|c|c|c}
\hline \hline Material & $\mathrm{K}\left[\mathrm{Bq} \mathrm{kg}^{-1}\right]$ & $\mathrm{Th}\left[\mathrm{Bq} \mathrm{kg}^{-1}\right]$ & $\mathrm{U}\left[\mathrm{Bq} \mathrm{kg}^{-1}\right]$ \\
\hline aggregate & 31 & - & 19 \\
andesite & 1294 & 156 & 101 \\
barite & 107 & 5 & - \\
tuff & 1193 & 173 & 124 \\
olivine & - & 3 & - \\
pumice & 1166 & 145 & 93 \\
\hline
\end{tabular}

(-) not detectable.

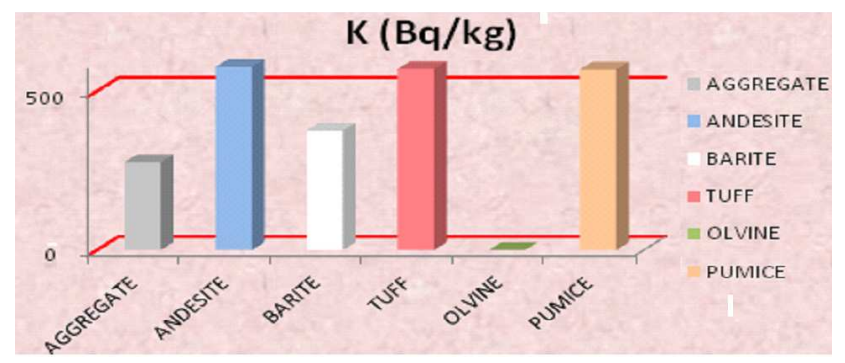

Fig. $1 .{ }^{40} \mathrm{~K}$ activity of materials.

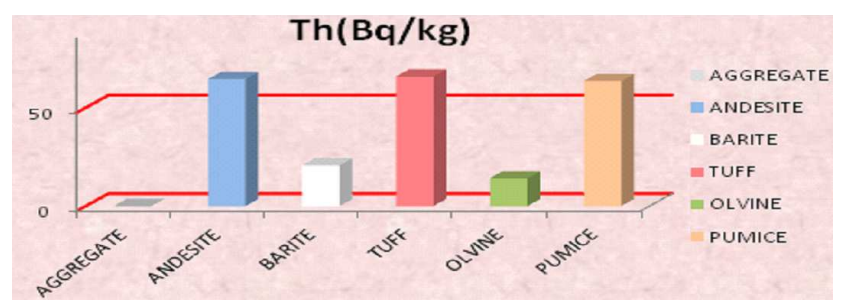

Fig. 2. $\quad{ }^{232}$ Th activity of materials.

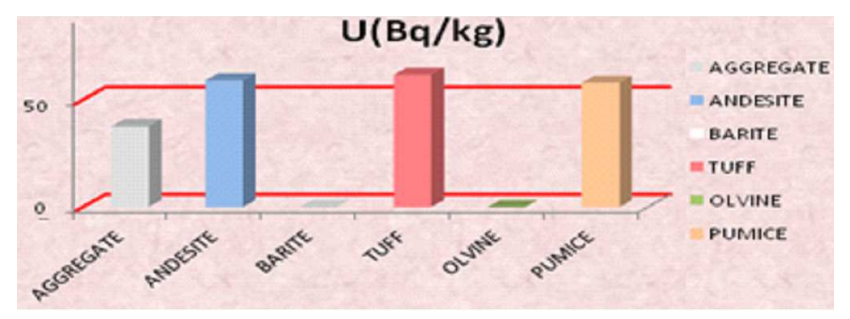

Fig. 3. ${ }^{238} \mathrm{U}$ activity of materials.

It can be seen from Table I that the potassium isotope contributes to the most specific activity compared with the other isotopes and the lowest value of ${ }^{238} \mathrm{U}$ concentration. The highest value for ${ }^{232} \mathrm{Th}$ was $173 \mathrm{~Bq} \mathrm{~kg}^{-1}$ recorded in tuff sample. The lowest and highest values for ${ }^{40} \mathrm{~K}$ were not measured and $1294 \mathrm{~Bq} \mathrm{~kg}^{-1}$ in olivine and andesite, respectively.

Average values obtained for each material and the limit values UNSCEAR 2000 [11] are compared in Fig. 1. In olivine, $\mathrm{K}\left[\mathrm{Bq} \mathrm{kg}^{-1}\right]$ there could not be detected activity. Andesite, tuff, pumice were above the limit values.

${ }^{232} \mathrm{Th}$ activity of building materials are shown in Fig. 2. As shown in Fig. 2, the highest value for ${ }^{232} \mathrm{Th}$ was recorded in tuff, while the lowest - in aggregate. Andesite, tuff, pumice were above the limit values.

${ }^{238} \mathrm{U}$ activity of building materials are shown in Fig. 3 . As shown in Fig. 3, the highest value was recorded in tuff while the lowest - in olivine. Andesite, tuff, pumice were above the limit values.

Materials as olivine and barite could not be detected. Andesite, tuff, pumice were above the limit value of the calculated radium equivalent activity $\left(\mathrm{Ra}_{\mathrm{eq}}\right)$ and are given in Table II.

\section{TABLE II}

Radium equivalent $\left(\mathrm{Ra}_{\mathrm{eq}}\right)$ activity.

\begin{tabular}{c|c}
\hline \hline Material & $\mathrm{Ra}_{\mathrm{eq}}\left[\mathrm{Bq} \mathrm{kg}^{-1}\right]$ \\
\hline aggregate & 21.38 \\
andesite & 423.71 \\
barite & 15.38 \\
tuff & 463.25 \\
olivine & 4.29 \\
pumice & 390.13
\end{tabular}

From the obtained results (in Table II) it can be noticed that the lowest of $\mathrm{Ra}_{\mathrm{eq}}$ is $4.29 \mathrm{~Bq} \mathrm{~kg}^{-1}$ calculated in olivine while the highest value is $463.25 \mathrm{~Bq} \mathrm{~kg}^{-1}$ in tuff. The high values for $\mathrm{Ra}_{\mathrm{eq}}$ are derived from high ${ }^{40} \mathrm{~K}$ content in the sample. To monitor the radioactivity levels of materials, the radium equivalent activities of these materials should be determined. The recommended maximum levels of $\mathrm{Ra}_{\mathrm{eq}}$ for building materials to be used for homes and industries are $<370$ and $370-740 \mathrm{~Bq} \mathrm{~kg}^{-1}$, respectively [12]. Andesite, tuff, pumice remained higher than this value. 
TABLE III

External radiation risk.

\begin{tabular}{c|c}
\hline \hline Material & $H_{\mathrm{ex}}$ \\
\hline aggregate & 0.057 \\
andesite & 1.14 \\
barite & 0.041 \\
tuff & 1.28 \\
olivine & 0.011 \\
pumice & 1.04
\end{tabular}

External radiation risk $\left(H_{\mathrm{ex}}\right)$, the results are given in Table III. Aggregates, barite, olivine samples of materials obtained from the results of $H_{\mathrm{ex}}$ values are much lower than the value of 1 . Pumice, andesite, and tuff materials are higher than value of 1 .

\section{Results and recommendations}

In this study, obtained from Isparta region, for barites, olivine, aggregate, natural radiation levels were below the limit values. Andesite, pumice, tuff, materials were slightly above the limit values. The reason is due to the fact that they are volcanic rock. This material may not be suitable for indoor use, suitable for outdoors.

\section{References}

[1] Aggregates: Sand, Gravel and Crushed Rock Aggregates for Construction Processes, Eds. M.R. Smith, L. Collis, P.G. Fookes, No. 17, Geological Society, London 2001.

[2] J. Beretka, P.J. Matthew, Health Phys. 48, 87 (1985).
[3] R. Hewamann, C.S. Sumithrarachchi, P. Mahawatte, H.L.C. Nanayakkara, H.C. Ratnayake, Appl. Radiat. Isotopes 54, 365 (2001).

[4] Ş. Turhan, J. Environm. Radioactiv. 99, 404 (2008).

[5] A. Nour Khalifa, J. Environm. Radioactiv. 83, 91 (2005).

[6] A. Kumar, M. Kumar, B. Singh, S. Singh, Radiat. Measur. 36, 465 (2003).

[7] O. Baykara, Ş. Karatepe, M. Doğru, Radiat. Measur 46, 153 (2011)

[8] L. Xinwei, Radiat. Measur. 40, 94 (2005).

[9] F. Asgharizadeh, A. Abbasi, O. Hochaghani, E.S. Gooya, Radiat. Prot. Dosim. 149, 321 (2012).

[10] European Commission (EC), Radiation Protection 112. Radiological Protection Principles Concerning the Natural Radioactivity of Building Materials. Directorate - General Environment, Nuclear Safety and Civil Protection, 1999.

[11] UNSCEAR, United Nations Scientific Committee on the Effects of Atomic Radiation. Sources, effects and risks of ionizing radiation. Report to the General Assembly with Annex B: Exposures from Natural Sources of Radiation, United Nations, New York 2000.

[12] M.O. Oresegun, A.I. Babalola, in: Proc. Int. Conf. on Radiation Protection in Nuclear Energy, Vol. 2, IAEA, Vienna 1988, p. 159. 